\title{
IJTIHAD 'VIRTUAL' DAN FIQIH CORONA: RESPON ULAMA INDONESIA DI MUSIM PANDEMI
}

\author{
Abdul Wafi Muhaimin \\ Ma'had Aly al-Musthafawiyah \\ wafimuhaimin@gmail.com
}

\begin{abstract}
Covid-19 has been announced as global pandemic by World Health Organization (WHO). All countries, including Indonesia, implemented the health protocols in preventing the spread of viruses. Among those protocols is social distancing either in lockdown or physical distancing. This policy disrupted the life order and habit, especially in religious ritual. The religious problems should be answered by the ulamas for the law certainty. In the normal situation, the discussion on fatwa is usually held by collective ijtihad (Ijtihad Jama'i). This way is done by MUI and its fatwa commission, NU and Its Bahtsul Masail, Muhammadiyah and Its Majlis Tarjih. Unfortunately, in covid-9 pandemic, the meeting for collective ijtihad is not easy to do because of the healthy protocol. Instead of that, the discussion to determine fatwa should be done as responding religious problems, but by virtual ijtihad via Zoom and others application, such as whatsapp groups. Therefore, this article discuss about the way ulamas responds the law-religious problems during Covid-19 pandemic.
\end{abstract}

Keywords: Ijtihad; Virtual; Fiqh; Corona

\begin{abstract}
Abstrak
Covid-19 telah ditetapkan sebagai pandemi global oleh World Health Organization (WHO) sehingga berbagai negara, termasuk Indonesia, menetapkan protokol kesehatan dalam upaya pencegahan penyebaran virus ini. Salah satunya adalah dengan melakukan social distancing baik dengan cara lockdown maupun hanya dengan melakukan physical distancing. Kebijakan ini tentu berpengaruh terhadap tatanan kehidupan manusia, termasuk dalam ritual keagamaan. Tentu persoalan keagamaan harus mendapatkan jawaban dari para ulama agar umat mendapatkan kepastian hukum. Problemnya adalah, setiap persoalan hukum biasanya dalam kondisi normal dilakukan dengan cara kolektif (ijtihad jama'i), baik yang dilakukan oleh MUI dengan komisi fatwanya, NU dengan Lembaga Bahtsul Masailnya, Muhammadiyah dengan Majlis Tarjihnya, dan ormas-ormas lainnya. Namun dalam kondisi seperti sekarang ini (masa pandemi Covid-19) tentu tidak mudah untuk dilakukan. Maka muncullah terobosan baru dengan cara memaksimalkan kecanggihan teknologi, sehingga persoalan keummatan tetap bisa direspon dengan baik melalui ijtihad 'virtual', baik dengan cara melalui aplikasi Zoom maupun melalui chatting dengan memaksimalkan group-group Whatsapp (WAG). Oleh karena itu, kajian ini akan membahas tentang bagaimana para kyai (ulama) merespons persoalan hukum selama pandemi Covid-19.
\end{abstract}

Kata Kunci: Ijtihad; Virtual; Fiqih; Corona 


\section{PENDAHULUAN}

Dalam kamus bahasa, virtual adalah suatu kata sifat yang berkaitan dengan hasil budi pekerti, bisa berupa karya buah pikiran yang bersifat maya atau imajinatif namun bisa diaplikasikan juga dalam dunia perkembangan teknologi modern seperti internet. ${ }^{1}$ Maka yang dimaksud dengan ijtihad virtual dalam pembahasan ini adalah, usaha sungguhsungguh para ulama dalam melahirkan hukum dengan peralatan teknologi, baik melalui via teleconference seperti zoom, video call, dan lain semacamnya, maupun via chatting seperti whatsapp, facebook dan lain sebagainya. Oleh karena itu, ijtihad kolektif (jama’i) ${ }^{2}$ di era teknologi ini sangat memungkinkan untuk dilakukan tanpa harus membutuhkan waktu lama karena jarak yang jauh dan biaya yang mahal. Perlunya ijtihad kolektif dalam kondisi sekarang ini karena sulit menemukan tokoh-tokoh yang menguasai segala bidang keilmuan, sehingga ijtihad tidak memungkinkan untuk dilakukan secara individual (fardi). Maka ijtihad kolektif (jama'i) merupakan solusi terbaik dalam memecahkan kebuntuan hukum di era teknologi ini, ${ }^{3}$ dan dengan ijtihad kolektif melalui sarana teknologi sangat dimungkinkan tercapainya sebuah konsensus (ijma) ulama yang selama ini boleh jadi hanya sebagai warisan sejarah karena sulitnya untuk dilakukan. ${ }^{4}$

Ijtihad adalah usaha mengerahkan kemampuan untuk menemukan hukum-hukum syara' sampai tingkat zhan (dugaan kuat) sehingga mujtahid tersebut merasakan tidak bisa lagi berupaya lebih dari itu, ${ }^{5}$ atau pengerahan sungguh-sungguh kemampuannya dalam upaya menemukan hukum yang berhubungan dengan amal perbuatan dari satu persatu dalilnya. ${ }^{6}$ Kerja ijtihad inilah yang menjadi salah satu faktor dunia Islam pernah mengalami masa kejayaannya (golden age). Hanya saja pada perkembangan berikutnya, pelukisan tentang kegiatan ijtihad sebagai sesuatu yang amat eksklusif telah melahirkan persepsi salah, sehingga sempat tumbuh pandangan yang hampir menabukan ijtihad. Penabuan ini disebabkan upaya ulama meredam kekacauan menjelang keruntuhan kota Baghdad, dan

\footnotetext{
${ }^{1}$ https://Id.m.wiktionary.org/wiki/virtual

2 Mengenai definisi ijtihad jama'i, lihat: Sya'ban Isma'il, al-Ijtihad al-Jama'i wa Daur al-Majami' al-Fiqhiyyah fi Tathbiqihi, (Beirut: Dar al-Basyair, 1998), h. 21, Abdul Majid al-Susuh al-Syarafi, al-Ijtihad al-Jama'i fi al-Tasyri' alIslami, (Wizarah al-Auqaf wa al-Syu'un al-Islamiyah: Silsislah Kitab al-Ummah, 1418 H.), h. 46, al-Abd Khalil, alIjtihad al-Jama'i wa Ahammiyatuhu fi al-Ashr al-Hadits, h. 215, dan Quthb Sanu, al-Ijtihad al-Jama'i al-Mansyud, (Dar alNafais, 2006), h. 53.

${ }^{3}$ Ijtihad jama'i merupakan kegiatan ijtihad yang yang melibatkan berbagai disiplin ilmu di samping ilmu fiqih itu sendiri sesuai dengan permasalahan yang akan dibahas. Hal ini mengingat, masalah-masalah yang bermunculan, ada yang berkaitan dengan ilmu selain ilmu fiqih, seperti kedokteran, pertanian dan ilmu-ilmu social yang behubungan dengan permasalahan yang akan dibahas. Lihat: Satria Effendi, Ushul Fiqh, $4^{\text {th }}$ ed., (Jakarta: Kencana Prenada Media Group, 2012), h. 258-259.

${ }^{4}$ Menurut jumhur ulama, kata Muhammad Abu Zahrah, ijma sudah diangap sah dengan adanya kesepakatan dari mayoritas ulama mujtahid, dan kata Abdul Karim Zaidan, Ijma' baru bisa dianggap terjadi bilamana merupakan kesepakatan seluruh ulama mujtahid.

${ }^{5}$ al-Amidi, al-Ihkam fi Ushul al-Ahkam, Vol. 3, h. 139

6 'Abdul Wahhab Khallaf, Ilm Ushul al-Fiqh, 12 ${ }^{\text {th }}$ eds, (DÉr al-Qalam, 1978), h. 216.
} 
sebagai kelanjutan dari masa kegelapan (obskurantisme) dalam pemikiran Islam. ${ }^{7}$ Oleh karena itu, jumhur ulama ushul fiqih berpandangan bahwa, pada masa tertentu mungkin akan terjadi kevakuman dari ijtihad bilamana hasil-hasil ijtihad di masa lampau masih dianggap cukup untuk menjawab masalah-masalah yang muncul di kalangan umat Islam. ${ }^{8}$

Namun begitu, tidak ada satu masa yang boleh kosong dari kegiatan ijtihad karena selalu banyak masalah-masalah baru yang harus di jawab. Sementara teks agama sudah selesai semenjak wafatnya Nabi Muhammad, sedangkan fenomena (kasuistik) senantiasa terus berjalan dan berubah (al-nushush mutanahiyah wa al-waqai' gharu mutanahiyah). Jika kerja ijtihad tidak dilakukan, maka adegium Islam agama yang responsif (shalih likulli zaman wa makan) hanya akan menjadi pembelaan atas kekalahan umat Islam. Oleh sebab itu, tokoh-tokoh pembaru seperti Muhammad Abduh dan Sayyid Khan mengajukan ijtihad sebagai salah satu tema pokok usaha reformasi atau penyegaran kembali pemahaman terhadap agama, atau metode terpenting untuk menghilangkan situasi anomallous ${ }^{9}$ dunia Islam yang kalah dan dijajah oleh dunia Kristen Barat. ${ }^{10}$

Hidupnya praktek ijtihad yang dilakukan oleh para ulama dan cendekiawan Muslim merupakan faktor eksisnya hukum Islam dalam setiap masa. Ijtihad tersebut sebagai respon dari perkembangan masyarakat dan perubahan social yang mengitarinya. Para mujtahid berkeyakinan bahwa hukum Islam akan selalu up to date karena memiliki daya elastis. Elastisitas dapat dilihat antara lain dari sedikitnya jumlah ayat hukum (ayat al-ahkam) dalam al-Qur'an dan hadis-hadis hukum dalam berbagai kitab hadis. Itu pun pada umumnya hanya memuat norma-norma dasar yang bersifat umum dan global. Sebaliknya, hukum Islam akan tertinggal dari sektor-sektor kehidupan yang lain dalam masyarakat apabila produktivitas ijtihad para ulama terhenti dan hukum Islam tidak dapat memenuhi kebutuhan masyarakat, sehingga akan terjadi hambatan-hambatan dalam sektor-sektor kehidupan bahkan dapat menimbulkan disorganisasi dengan memudarnya kaidah-kaidah lama, sementara kaidah-kaidah baru belum tersusun. Kondisi demikian bisa pula berlanjut

\footnotetext{
${ }^{7}$ Lihat: Nurcholish Madjid dalam Taklid dan Ijtihad: Masalah Kontinuitas dan Kreativitas dalam Memahami Pesan Agama, norcholishmadjid.org/arsip-karya/read/7-1994-taklid-dan-ijtihad, h. 13. Terkait dengan factor tertutupnya pintu ijtihad pada abad ke 10 M., direkam dengan baik oleh Abdul Wahhab Khallah, Khulashah Tarikh al-Tasyri' alIslami, (Kuwait: Dar al-Qalam, t.th.), h. 99-102.

${ }^{8}$ Satria Effendi, Ushul Fiqh, h. 246.

${ }^{9}$ Disebut anomallous karena selama paling kurang tujuh atau delapan abad, orang-orang muslim terbiasa berpikir bahwa dunia ini milik mereka, dan hak mengatur dunia hanya ada pada mereka, sebagai salah satu akibat penguasaan mereka atas daerah-daerah sentral peradaban manusia, terutama daerah Nil sampai Oxus, jantung kawan (Oikoumene).

${ }^{10}$ Dikutip oleh Nurcholish Madjid dalam Taklid dan Ijtihad: Masalah Kontinuitas dan Kreativitas dalam Memahami Pesan Agama, h. 13
} 
dengan terjadinya anomie, yaitu keadaan kacau karena tidak adanya pegangan masyarakat. $^{11}$

Oleh karena itu, hal penting dalam kondisi hari ini, dimana manusia dihadapkan pada kondisi tidak normal (pandemi Covid-19), ulama dituntut untuk menjawab porsoalan-persoalan hukum yang boleh jadi tidak pernah ditemukan padanannya dalam warisan ulama-ulama masa lalu. Konsep fiqih ulama masa lalu bisa dibilang sangat sederhana karena memang kondisi zamannya menuntut seperti itu. Pada masanya, bisa jadi belum ada transaksi jual-beli via internet (Shopee, Bukalapak, Lazada, dll.), atau menikah via teleconference (zoom atau video call, dan lain sebagainya), sehingga konsep pada waktu itu sesuai dengan kebutuhan yang dihadapi, baik dalam urusan jual beli, pernikahan, maupun yang lainnya. Oleh karena itu, ijtihad kolektif 'virtual' dalam kondisi pandemi ini sangat penting dilakukan dengan cara para pakar melakukan musyawarah via teleconference untuk memecahkan persoalan-persoalan yang dihadapi, terutama yang menyangkut hajat orang banyak.

\section{METODE}

Pada dasarnya, penelitian ini bersifat kualitatif yang menitikberatkan pada kajian kepustakaan (library research) dan akan menghasilkan data deskriptif, ${ }^{12}$ sehingga memerlukan pendekatan deskriptif analisis. Dengan demikian, kajian ini hanya berorientasi pada referensi hasil karya para pakar hukum Islam termasuk mufassir dan orang-orang yang berkompetensi di bidang Ijtihad dan Fiqh. Penelitian deskriptif ini lebih berfokus pada studi teks-teks yang memerlukan olahan uji empirik di lapangan melalui hasil penelitian yang telah ada, dan studi pustaka yang menekankan olahan filosofik dan teoritik dari pada uji empirik. Kedua model penelitian pustaka ini digunakan untuk menganalisa teks (content analysis) yang diharapkan bisa memenuhi tiga persyaratan, yakni obyektifitas, sistematis, dan generalisasi.

\section{PEMBAHASAN}

\section{Corona dan Kontekstualisasi Fiqih}

\footnotetext{
${ }^{11}$ Muhammad Iqbal, The Reconstruction of Religious, Thought in Islam, (New Delhi: Ktab Bavan, 1981), h. 148, yang dikutip oleh Badri Khaeruman, Hukum Islam Dalam Perubahan Sosial, (Bandung: Pustaka Setia, 2010).

${ }^{12}$ Lexy J. Moeloeng, Metode Penelitian Kualitatif, (Bandung: Remaja Rodakarya, 1997), Cet. VIII, h. 3.
} 
Produk hukum yang dihasilkan melalui ijtihad dengan berbagai metodenya, ${ }^{13}$ di dunia Islam dikenal dengan istilah "fiqih". Sejak awal kelahirannya, fiqih menerima perubahan dan bersifat elastis, sehingga senantiasa responsif sepanjang sejarahnya. Oleh karena itu, dalam konteks pandemi Covid-19, kontekstualisasi fiqih merupakan sebuah langkah di mana fiqih akan senantiasa mampu menjawab berbagai persoalan yang dihadapi umat. Karena jika kontekstualisasi teks (fiqih) tidak dilakukan, maka tidak menutup kemungkinan teks-teks fiqih klasik hanya akan menjadi warisan masa lalu yang patut dimusiumkan.

Menurut al-Qarafi, sikap terpaku secara terus-menerus pada teks pendapat ulama terdahulu adalah suatu kesesatan dalam agama dan (juga) suatu ketidak mengertian terhadap apa yang diinginkan oleh para ulama terdahulu. ${ }^{14}$ Ia menyarankan untuk tidak terpaku hanya pada apa yang tertulis dalam kitab-kitab. Oleh karena itu, jika datang seorang peminta fatwa (mustafti) dari luar daerah, maka hendaknya tidak menerapkan sebuah hukum menurut tradisi yang berlaku di daerah sang mufti (pemberi fatwa). Seorang mufti harus menanyakan terlebih dahulu kepada peminta fatwa tentang tradisi yang berjalan di daerahnya. Kemudian mufti memberikan fatwa berdasarkan tradisi di daerah sang mustafti bukan berdasarkan tradisi yang ada di daerah sang mufti dan bukan pula berdasarkan keputusan yang tercantum dalam kitab-kitabnya. ${ }^{15}$

Sebagaimana al-Qarafi, Ibnu al-Qayyim berpendapat yang sama bahwa, siapapun yang berfatwa hanya dengan melihat pada teks yang tertuang dalam kitab-kitab (fiqih), padahal berbeda budaya, adat, situasi, kondisi, dan indikasinya, maka sungguh telah sesat dan menyesatkan. ${ }^{16}$ Oleh karena itu, menurut Ibn al-Qayyim, jika ada orang yang meminta fatwa (mustafti) dari wilayah atau negara berbeda, maka seorang pemberi fatwa (mufti) harus menanyakan terlebih dahulu budayanya. Mufti akan memberikan fatwa sesuai dengan budaya peminta fatwa bukan sesuai dengan budaya yang termaktub dalam kitab karangannya. ${ }^{17}$

Menurut Zahro, sebagai karya ilmiah, kitab fiqih tentu harus dihargai dan penulisnya patut dihormati, serta hasil ijtihadnya boleh didukung dan diikuti. Namun sebagai karya

\footnotetext{
${ }^{13}$ Metode ijtihad didomenasi oleh qiyas, sehingga imam Syafi'i menyamakan ijtihad dengan qaiyas. Namun dalam kasus tertentu, ulama menggunakan metode lainnya seperti istihsan, istishlah, sadd al-dzariah, dan lain sebagainya.

${ }^{14}$ Teks Arabnya:

على المنقولات أبدا ضلال في الدين وجهل بمقاصد علماء المسلمين والسلف الماضين. الجمود

${ }^{15}$ AÍmad bin Idris al-Qarafi, al-Furuq, vol. 1, (Beirut: Dar al-Kutub al-'Ilmiyyah, 1998), h. 176, atau alQarafi, al-Furuq, vol. II, (Beirut: Dar al-Gharb al-Islami, 1994), h. 176-177.

${ }^{16}$ Teks Arabnya:

ومن أفتى الناس بكجرد المنقول في الكتب على اختلاف عرفهم، وعوائدهم، وأزمنتهم، وأحوالهم، وقرائن أحوالهم، فقد ضل وأضل.

${ }^{17}$ Ibn al-Qayyim al-Jawziyyah, I'lÉm al-Muwaqqi 'Ến 'an Rabb al- 'ÓlamÊnn, Vol. 1, (al-RiyÉİ: DÉr Ibn al-JawzÊE, 1423 H.), h. 52.
} 
ilmiah pula, kitab fiqih bukanlah kitab yang mesti disakralkan, penulisnya tidak boleh dikultuskan, serta hasil ijtihadnya tidak tabu dipersoalkan. Lebih lanjut, Zahro mengatakan bahwa kitab fiqih memang merupakan karya monumental para ulama brilian yang sesuai untuk masanya, dan cocok bagi zamannya, serta valid pada waktunya. Tetapi sebagai produk pemikiran manusia, apalagi kitab-kitab yang sudah berusia ratusan tahun, tentu amat wajar manakala dikemudian hari ditemukan hal-hal yang terasa tidak relevan lagi dengan perkembangan zaman yang amat cepat perubahannya lantaran dipacu oleh kemajuan ilmu pengetahuan, kecanggihan teknologi dan globalisasi informasi. ${ }^{18}$

Senada dengan Ahmad Zahro, menurut kyai Sahal Mahfudh bahwa jika pola pemahaman tekstual tidak segera diimbangi dengan pola-pola pemahaman kontekstual, maka bukan mustahil jika kitab kuning akan menjadi harta pusaka yang hanya bisa dimiliki tetapi tidak banyak memberikan manfaat bagi solusi permasalahan aktual. Bahkan lebih tragis lagi adalah pemahaman tekstual bisa menyeret kaum muslimin memperlakukan fiqih sebagai dogma yang tidak bisa diganggu gugat. Tidak jarang, fiqih (kitab kuning) dianggap sebagai kitab suci kedua setelah al-Qur'an. Lebih lanjut lagi, menurut kyai Sahal, gagasan pemahaman kontekstual bukan berarti meninggalkan dan menanggalkan fiqih secara mutlak, justru segala aspek perilaku kehidupan akan dapat terjiwai oleh fiqih secara konseptual dan tidak menyimpang dari rel fiqih itu sendiri. ${ }^{19}$

Semangat kontekstualisasi merupakan semangat untuk menangkap pesan dari teks. Teks (fiqih) tidak lahir dari ruang kosong. Fiqih lahir dari konteks dimana mujtahid itu lahir. Sehingga boleh jadi, ketika teks masa lalu ditarik dalam konteks hari ini, teks tersebut sudah tidak memenukan relevansinya. Boleh jadi, teks yang lahir ketika itu, merupakan respon terhadap kasus yang memuat kemaslahatan di dalamnya. Sementara kasus tersebut, bisa jadi hari ini sama secara bungkus dan merk namun muatannya sudah berbeda, sehingga tentu tidak bisa direspon dengan teks yang sama. Bahkan dalam waktu yang sama, namun berbeda secara kondisi geografis, maka respon hukumnya akan berbeda pula. Contoh sederhananya misalnya, memakai selimut di kawasan puncak gunung sangat dianjurkan. Namun anjuran ini tidak bisa diberlakukan untuk masyarat yang tinggal di padang pasir dengan cuaca panas. Contoh lain, memegang kepala orang lain di kawasan Arab mungkin dianggap biasa bahkan dianggap baik, namun tidak berlaku di Indonesia. Maka muncul kaidah fiqih bahwa, "Fatwa (hukum) dapat berubah disebabkan perubahan zaman, tempat, keadaan, kebiasaan, dan niat (motivasi)." ${ }^{20}$ Redaksi lain yang lebih singkat

\footnotetext{
${ }^{18}$ Lihat Makalah Ahmad Zahro, "Desakralisasi Kitab Fiqih Sebagai Upaya Reformasi Pemahaman Hukum Islam.” yang disampaikan dalam pengukuhan guru besar ilmu fikih (hukum Islam) Fakultas Tarbiyah IAIN Sunan Ampel (sekarang UINSA), 30 Juli 2005.

${ }^{19}$ Sahal Mahfudh, Nuansa Fiqh Sosial, $7^{\text {th }}$ ed., (Yogyakarta: LKiS, 2011), h. xxxix-xI.

${ }^{20}$ Lihat: Ibn Qayyim al-Jauziyah, I'lam al-Muwaqi' in 'an Rabb al-'Alamin, Vol. 3, (Beirut: Dar Jail, T.th.), h. 14. Redaksi Arabanya
} 
adalah "Tidak dapat dimungkiri bahwa hukum berubah karena perubahan keadaan (zaman)." 21

Oleh karena itu, tidak heran dalam kasus merespon persoalan seputar Covid-19 antara lembaga fatwa terkadang berbeda satu sama lainnya di dalam memberikan jawaban hukum. Bukan hanya disebabkan perbedaan negara, di dalam Indonesia saja, satu organisasi bisa berbeda dalam fatwanya, antara MUI DKI terkadang bebeda fatwanya dengan MUI Jawa Timur, LBM-PBNU terkadang berbeda dengan LBM-PWNU atau LBM-PCNU. Hal itu wajar, karena kondisi yang dihadapinya berbeda. Misalnya, DKI Jakarta sudah masuk zona merah, sementara Jawa Timur masih zona hijau atau sebaliknya. Maka respon hukumnya pun tentu akan berbeda pula. Malah menjadi lucu jika kondisinya tidak sama namun respon hukum sama, atau kondisinya sama namun respon hukumnya berbeda. Maka tentu, ulama membutuhkan kontekstualisasi atau mendialogkan teks dengan konteks sehingga keputusan hukumnya selaras dengan tujuan agama (maqashid alsyari'ah).

\section{Forum Ahli Fiqih Melalui WAG}

Sebuah group whatsapp dengan nama "Diskusi Fiqih Kontemporer", selanjutnya disingkat dengan DFK, dibuat pada 16 Mei 2020. Group ini diisi oleh aktifis bahtsul masail NU seluruh Indonesia yang anggotanya lebih dari 250 peserta. ${ }^{22}$ Dalam deskripsinya dijelaskan bahwa, group ini mendiskusikan pelbagai masalah keagamaan dengan merujuk pada fiqih empat mazhab Ahlussunnah wal-jama'ah. Group ini terlihat sangat resmi dengan dicantumkannya dewan perumus, dewan mushohih, moderator, notulen dan editor. Dilihat dari nama-namanya, baik para perumus maupun mushahih, ada beberapa tidak asing karena banyak yang terlibat di kepengurusan MUI dan NU. Misalnya dewan perumus seperti KH. Cholil Nafis, Lc. Ph.D (Ketua Komisi Dakwah MUI Pusat), KH. Yazid Fattah (Ketua Aswaja Center Jawa Barat.), KH. Khotimi Bahri (Ketua Komisi Fatwa MUI dan Ketua LBM-NU Kota Bogor), dan KH. Takhuri Wahmad (Ketua Jatman Depok). Sementara dewan mushohih ada KH. Hamdan Rasyid (Komisi Fatwa MUI Pusat) dan KH. Hidayatullah (Wakil Katib PWNU Jawa Barat). Bahkan ada juga dari Komnas HAM dan DPR RI. Sementara peserta yang aktif dalam forum diskusi ini rata-rata adalah alumni pondok pesantren ternama, seperti Lirboyo, Ploso, Sarang Rembang, Sidogiri, Nurul Jadid, Bata-Bata, Banyuanyar, al-Amin Prenduan, dan lain sebagainya, yang selama masih di pesantren dulu mereka menjadi aktivis bahtsul masail.

\footnotetext{
${ }^{21}$ Muhammad al-Zarqa, Syarh al-Qawaid al-Fiqhiyyat, (Damaskus: Darul Qalam, 1989), h. 227. Teks Arabnya: تغير الفتوى بتغير الأزمان والأمكنة والأحوال والعوائد والنيات.

${ }^{22}$ Jika ingin bergabung bisa masuk ketautan link:https:// chat.whatsapp.com/EBExnbQIPy QenysKazvqZI
} لا ينكر تغير الأحكام بتغير الأزمان. 
Forum ini hampir setiap hari menyelesaikan satu kasus hukum yang biasanya dimulai ba'da isya' (19.30) sampai keesokan harinya. Persoalan yang diangkat merupakan persoalan aktual yang ditanyakan oleh masyarat umum yang bergabung digroup facebook dengan nama yang sama, "Diskusi Fiqih Kontemporer". Setelah melalui proses jawaban yang melelahkan, hasil keputusannya diposting diwebsite dan di berbagai media lainnya. ${ }^{23}$ Diskusi dalam forum ini memiliki regulasi yang harus dipatuhi oleh semua peserta. Jika tidak patuh, maka akan mendapatkan teguran dari admin dan bahkan dikeluarkan dari group. Pertama, regulasi mengenai teknis, bahwa (a) pembahasan soal yang diproses terlebih dahulu adalah soal yang sudah terverifikasi oleh admin. Apabila soal sudah tuntas dan telah disepakati bersama, maka akan diposting di website www.pakarfiqih.blogspot.com dengan format yang berbeda, (b) menjawab soal yang sudah diposting beserta referensinya (nama kitab beserta halamannya) dari empat mazhab Ahlussunnah wal-jama'ah, yang diprioritaskan dari Syafi'iyyah terlebih dahulu sebelum lintas mazhab, (c) soal yang diprioritaskan terlebih dahulu adalah soal yang waqi'iyyah (terjadi di masyarakat), aktual, viral dan trending, dan urgen (mendesak). Kedua, larangan: (a) dilarang memosting hal-hal yang tidak berhubungan dengan diskusi fiqih atau keagamaan, seperti iklan, promosi, dan lain sebagainya. (b) bagi yang tidak mengindahkan instruksi tersebut, akan ditindak dengan tegas.

Sebagaimana nama forum ini, maka yang didiskusikan adalah isu-isu seputar masalah kekinian dan aktual. Namun begitu, forum ini masih tetap terjebak pada teks klasik (kutub al-shafra' al-mu'tabarah), sehingga walaupun yang dikaji adalah masalah kontemporer namun jawabannya masih menggunakan rujukan fiqih klasik. Sementara pendapat ulamaulama kontemporer hanya sekedar menjadi penunjang atau sebagai solusi. Tentu hal ini merupakan aktualisasi dari kaidah kaum pesantren "al-muhafazhah 'ala al-qadim al-shalih wa al-akhdzu bi al-jadid al-ashlah", merawat pendapat lama yang masih relevan dan mengadopsi pendapat baru yang lebih relevan. Para peserta diskusi sangat mahir di dalam mencari jawaban ('ibaroh) hukum dari kitab-kitab kuning yang otoritatif, sehingga forum diskusi ini layaknya seperti lomba mencari teks-teks berbasa Arab (musabaqah thalab al'ibarat), tetapi lemah secara metodologis (manhaji), atau boleh jadi banyak di antara peserta diskusi yang memahami ilmu ushul fiqih dan kaidah fiqih dengan baik, namun tidak memiliki keberanian untuk melakukan ijtihad. Sehingga ketika jawaban hukumnya tidak ditemukan secara eksplisit dalam kitab-kitab fiqih, maka mereka memilih tidak melanjutkan pembahasan (mauquf).

\section{Isu-isu Aktual Seputar Fiqih Corona}

\footnotetext{
${ }^{23}$ www.pakarfiqih.blogspot.com
} 
Tema-tema hukum di bawah ini adalah merupakan hasil keputusan yang dibahas dalam forum WA DFK. Keputusan hukum yang dipilih adalah keputusan yang berhubungan dengan kasus-kasus seputar Covid-19, antara lain:

1. Menghindari Berjabat Tangan di Masa Pandemi

Salah satu pembahasan yang dibahas dalam group whatsaap "Diskusi Fiqih Kontemporer" adalah mengenai hukum menghindari bersalaman dengan orang lain untuk menghindari tertularnya virus Corona di saat pandemi Covid-19. Setelah melakukan perdebatan panjang dan adu argumen, maka jawaban yang dihasilkan adalah, menghindari berjabat tangan (bersalaman) dengan orang lain untuk terhindar dari virus Corona dapat dibenarkan, mengingat hukum berjabat tangan dengan orang positif Covid-19 adalah makruh. Dan bagi setiap warga masyarakat tetap harus mengikuti protokol Covid-19 sesuai dengan ketetapan pemerintah.

Forum DFK memutuskan bahwa hukum berjabat tangan dengan orang yang positif Corona adalah makruh. Hukum ini dianalogikan dengan hukum berjabat tangan dengan orang yang terkena penyakit kusta (judzam). ${ }^{24}$ Salah satu referensi yang dijadikan rujukan adalah kitab al-Mausu'ah al-Fiqhiyah al-Kuwaitiyah dengan redaksi:

$$
\text { تكره مصافحة وتقبيل ومعانقة من به داء الجذام بهذا قال الشافعية }
$$

"Dimakruhkan berjabat tangan, mengecup, dan memeluk orang yang terkena penyakit kusta, sebagaimana pendapat Syafi iyah." 25

Tentu menganalogikan virus Corona dengan penyakit kusta perlu diuji kesamaan 'illatnya. Apakah sudah tepat menghukumi bersalaman dengan orang yang positif Corona hanya dengan hukum makruh sebagaimana bersalaman dengan orang yang tertular penyakit kusta, padahal potensi penularan virus Corona sangat besar. Artinya, kalau menggunakan pola pikir mafhum mukhalafah, jika tidak positif Corona maka berjabat tangan hukumnya bisa mubah dan bahkan bisa tetap sunnah sebagaimana hukum asal dari bersalaman. Sementara agama melarang umatnya untuk menjerumuskan dirinya kepada kebinasaan (al-Baqarah: 195).

\section{Pengurusan Jenazah Korban Covid-19}

Di sebuah rumah sakit, ada pasien yang meninggal dunia dalam status PDP (Pasien Dalam Pengawasan). Namun karena sampai meninggalnya hasil Swab belum keluar, maka pasien tersebut diperlakukan seperti pasien positif Covid-19 dengan cara ditayammumi.

\footnotetext{
${ }^{24}$ Lihat: Abu al-Qasim Ibn al-Syath al-Maliki, Idrar al-Syuruq 'ala Anwa' al-Furuq, Vol. 4, (Beirut: Dar al-Kutub al-'Ilmiyyah, t.th), h. 400-401, Syihabuddin al-Qarafi, al-Furuq, vol. 4, (h. 4001, al-Manar: 5/222, al-Qulyubi wa 'Umairah, HÉsyiyata Qulyubi wa 'Umairah, vol. 11, (al-Qahirah: Dar al-Taufiqiyah li al-Turats, 2010), h. 123, dan Wazarah al-Auquf wa al-Syu' un al-Islamiyyah, al-Mausu'ah al-Fiqhiyah al-Kuwaitiyah, vol. 27, h. 188.

25 al-Mausu'ah al-Fiqhiyah al-Kuwaitiyah: 15/132.
} 
Setelah beberapa hari dari penguburan, hasil test menunjukkan bahwa pasien tersebut negatif. Maka muncul pertanyaan bagaimana fiqih menyikapi kasus tersebut mengingat jenazah ternyata negatif. Jawaban yang dihasilkan adalah, pemusalaran (tajhiz) jenazah PDP tersebut sudah cukup, dan jenazah tidak perlu digali lagi, meskipun pada akhirnya terungkap bahwa ia negatif Covid-19. ${ }^{26}$ Tentu hal ini perlu dipastikan tayammum yang dilakukan oleh tim medis, apakah sudah sesuai dengan standar fiqih atau tidak.

Dalam Hasyiyah Jamal dijelaskan bahwa ketika seseorang tercegah untuk menggunakan air disebabkan ada udzur, maka hilang kewajiban menggunakan air untuk bersesuci, bahkan bisa menjadi haram menggunakannya. Larangan atau keharaman menggunakan air, apabila ada dugaan kuat (ghalabah al-zhan) akan terjerumus kepada sesuatu yang membahayakan. Oleh karena itu, adanya dugaan kuat menggunakan air dapat membahayakan sehingga menyebabkan keharaman menggunakannya, maka dalam kondisi tidak ada dugaan kuat, namun ada kekhawatiran karena mendapatkan pejelasan dari dokter akan tertularnya penyakit, maka boleh melakukan tayammum, walaupun di tempat itu terdapat air. $^{27}$

Keputusan di atas sama dengan panduan pemulasaran yang dikeluarkan oleh MUI, NU dan Muhammadiyah. Menurut MUI, pada proses pemandian jenazah dimungkinkan dengan proses pengucuran air ke seluruh tubuh, maka dilakukan dengan cara mengucurkan air. Namun apabila atas pertimbangan ahli terpercaya bahwa jenazah tidak dimungkinkan untuk dimandikan, maka dapat diganti dengan tayammum sesuai dengan ketentuan syari'ah. Apabila tidak dimungkinkan untuk dimandikan atau ditayammumi karena membahayakan petugas, maka dapat langsung dikafankan. Ketuantuan ini juga sama dengan ketentuan NU dan Muhammadiyah. ${ }^{28}$

\section{Shalat Jum'at Dua Gelombang}

MUI DKI Jakarta mengeluarkan fatwa bernomor 05 Tahun 2020 tentang hukum dan panduan salat Jum'at lebih dari satu kali pada saat pandemi Covid-19. Fatwa tersebut dikeluarkan setelah membaca surat dari Sekretaris Daerah DKI Jakarta nomor 469/-0.856 perihal permohonan panduan pelaksanaan peribadatan dan kegiatan keagamaan. Dalam pembuatan fatwa tersebut, MUI DKI menimbang sejumlah hal. Salah satunya adalah

\footnotetext{
${ }^{26}$ Sulaiman bin Umar al-Jamal, Hasyiyah al-Jamal, vol. 1, h. 208 dan vol. 2, h. 211, Ibn Hajar al-Haitami, alSyarwani dan al-Ubbadi, Tuhfah al-Muhtaj fi Syarh al-Minhaj wa Hawasyi al-Syarwani wa al-Ubbadi, vol. 1, (Beirut: Dar al-Fikr, 1997), h. 74-75, 346, 368, Nawawi al-Jawi, Nihayah al-Zain Syarh Qurrah al-'Ain, h. 151, Sulaiman alBujairimi, Hasyiyah al-Bujairimi 'ala al-Khatib, vol. 1, h. 296, Muhammad bin Ahmad al-Syarbini, Mughni al-Muhtaj ila Ma'rifah Alfazh al-Minhaj, vo. 1, h. 267, Muhyiddin al-Nawawi, al-Majmu’ Syarh al-Muhadzab, vol. 5, (Beirut: Dar alKotob al-Ilmiyyah, 2011), h. 229, dan Zakaria al-Anshari, Asna al-Mathalib fi Syarh Raudh al-Thalib, vol. 1, (Beirut: Dar al-Kutub al-Ilmiyyah, 2001), h. 332.

${ }^{27}$ Lihat: Sulaiman bin Umar al-Jamal, Hasyiyah al-Jamal, vol. 1, h. 208.

${ }^{28}$ Fatwa MUI nomor 14 Tahun 2020, Buku Fiqih Pemulasaran Jenazah Pasien Covid-19 yang dikeluarkan oleh LBM-PBNU, dan Maklumat Pimpinan Pusat Muhammadiyah nomor 02/MLM/I.0/B/2020.
} 
terkait kebijakan protokol kesehatan yang menyebabkan masjid-masjid di Jakarta tidak akan mampu menampung seluruh jemaah shalat Jum'at dikarenakan harus melakukan jaga jarak (physical distancing) antar jamaah.

Maka pertanyaan yang muncul kemudian adalah, bagaimana hukum shalat Jum'at dua gelombang di masjid yang sama, akibat physical distancing sehingga masjid tidak tertampung. Jawaban yang muncul ada tiga opsi: Opsi pertama, hukum shalat jum'at dua gelombang di dalam satu masjid adalah tidak boleh, kecuali ada hajat seperti tempatnya sempit dan tidak ada masjid lain yang bisa digunakan untuk pelaksanaan shalat jum'at. Opsi kedua, hukum shalat jum'at dua gelombang di dalam satu masjid adalah boleh dengan syarat adanya hajat, semisal tempatnya sempit dan tidak adanya masjid lain yang bisa digunakan untuk melaksanakan shalat jum'at. Opsi ketiga, hukum shalat jum'at dua gelombang di dalam satu masjid adalah tidak boleh. Namun begitu, ulama berbeda pendapat dalam kondisi ada hajat semisal tempatnya sempit dan tidak ada masjid lain yang bisa digunakan untuk pelaksanaan shalat jum'at. Ada yang membolehkan seperti fatwa Syaikh Ali Jum'ah, fatwa ulama Eropa, dan ada yang tetap tidak memperbolehkan seperti Syaikh Mahmut Syaltut dan MUI. ${ }^{29}$

Kalau diperhatikan dari ketiga opsi jawaban tersebut, sebetulnya secara substansi sama. Opsi satu dan opsi dua hanya berbeda pada penekanan saja (stressing) yang pada intinya sama-sama membolehkan dalam kondisi adanya hajat semisal tempatnya sempit dan tidak ada masjid lain yang bisa digunakan untuk pelaksanaan shalat jum'at. Sementara opsi ketiga hanya sekedar menjelaskan perbedaan pendapat ulama. Opsi ketiga ini hampir sama dengan hasil keputusan fatwa MUI. Dalam pandangan MUI mengenai penyelenggaraan shalat Jum'at, bahwa pada dasarnya shalat jum'at hanya dapat diselenggarakan sekali di satu masjid dalam sebuah kawasan. Namun, jika jamaah shalat tidak dapat tertampung semuanya karena adanya perenggangan shaf, maka boleh melakukan shalat jum'at berbilang (ta'addud al-jum 'ah) di tempat lainnya seperti mushalla, aula, gedung pertemuan, gedung olahraga, dan stadion. ${ }^{30}$

Sidang Komisi Fatwa MUI berbeda pendapat dalam hal masjid dan tempat lain masih tidak menampung jamaah salat Jum'at dan/atau tidak ada tempat lain untuk pelaksanaan salat Jum'at. Pendapat pertama, jamaah boleh menyelenggarakan salat Jum'at di masjid atau tempat lain yang telah melaksanakan salat Jum'at dengan model shift, dan pelaksanaan salat Jum'at dengan model shift hukumnya sah. Pendapat kedua, jamaah melaksanaan salat zuhur, baik secara sendiri maupun berjamaah dan pelaksanaan salat

${ }^{29}$ al-Termasi, Vol. 3, h. 212, Ibn Hajar al-Haitami, al-Fatawa al-Fiqhiyah al-Kubra, Vol. 1, (Mesir: al-Maktabah al-Islamiyah, t.th.), h. 350, Nawawi, Nihayah al-Zain..., vol. 1, h. 139, al-Subki, Fatawa al-Subki, vol. 1, h. 186, alInshaf, vol. 2, h. 280, al-Sail al-Jirar, vol. 1, h. 301, dan al-Talkhish al-Habir, vol. 2, h. 136.

${ }^{30}$ Fatwa MUI Nomor 31 Tahun 2020 tentang penyelenggaraan shalat jum'at dan jamaah untuk mencegah penularan wabah covid-19. 
Jum'at dengan model shift hukumnya tidak sah. Terkait perbedaan pendapat tersebut, dalam pelaksanaannya, jamaah dapat memilih salah satu di antara dua pendapat dengan mempertimbangkan keadaan dan kemaslahatan di wilayah masing-masing. ${ }^{31}$

Sementara Lembaga Bahtsul Masail Pengurus Besar Nahdlatul Ulama (LBM PBNU) merespons kebijakan pemerintah perihal tatanan normal baru (new normal) dengan mengeluarkan hasil musyawarah mereka terkait tata cara pelaksanaan shalat Jum'at pada masa tatanan normal baru. LBM PBNU mengangkat pembahasan cara pelaksanaan shalat Jum'at dengan tetap memperhatikan protokol kesehatan, kemungkinan membuat (memperbanyak) tempat baru pelaksanaan ibadah Jum'at, dan kemungkinan pelaksanaan shalat Jum'at secara bergelombang di tempat yang sama. LBM PBNU menyatakan bahwa shalat Jum'at harus dilaksanakan satu kali pada satu tempat di setiap kawasan, desa atau kota. LBM-PBNU mengutip pendapat jumhur ulama bahwa, tidak boleh ada shalat Jum'at lebih dari satu kali (ta'addudul Jum'at) baik di tempat yang sama maupun tempat yang berbeda. Sebab, kalau ta'addudul Jum'at itu terjadi, maka pelaksanaan yang sah hanya shalat Jum'at yang pertama sebagaimana dikutip dalam kitab Minhaj al-Thalibin karya Imam an-Nawawi. LBM-PBNU menjelaskan bahwa ta'addudul Jum'at dimungkinkan karena ada uzur. Mereka merujuk pada kitab Bughyatul Mustarsyidin karya Abdurrahman Ba'alawi. Ketidak-bolehan ta'addudul Jum'at tidak bersifat mutlak sehingga ta'addud dapat ditempuh dengan mempertimbangkan tiga kebutuhan, yaitu keterbatasan daya tampung tempat shalat Jum'at, adanya pertikaian yang tidak memungkinkan pelaksanan shalat Jum'at pada satu lokasi, dan jarak tempuh penduduk yang tinggal di ujung sebuah kawasan (balad) dan masjid yang menjadi tempat pelaksanaan shalat Jum'at. LBM-PBNU mengatakan bahwa pandangan fiqih ulama terdahulu itu dapat dijadikan acuan hukum perihal pelaksanaan shalat Jum'at pada di era tatanan normal baru. Secara teknis, umat Islam misalnya dapat memanfaatkan mushala-mushala sebagai tempat shalat Jum'at. Adapun ketika pelaksanaan shalat Jum'at di beberapa tempat tidak mungkin untuk ditempuh karena kebijakan pemerintah (seperti pada sebagian negara di luar negeri), kebijakan di perkantoran, atau uzur lainnya, LBM PBNU mengemukakan perbedaan dua pendapat ulama. Pertama, sebagian ulama membolehkan pelaksanaan shalat Jum'at dua atau lebih gelombang pada lokasi yang sama dengan tetap mempertimbangkan jumlah jamaah (40 orang) dan kebutuhan untuk mengadakan gelombang shalat Jum'at di samping verifikasi lapangan untuk memastikan kebolehan ta'addudul Jum'at di satu kawasan. Kedua, sebagian ulama lainnya menyatakan bahwa pelaksanaan shalat Jum'at secara bergelombang pada satu tempat bukan solusi ketika ta'addud al-Jum'at tidak mungkin

${ }^{31}$ Fatwa MUI Nomor 31 Tahun 2020 tentang penyelenggaraan shalat jum'at dan jamaah untuk mencegah penularan wabah covid-19. 
dilakukan di tempat lain. Mereka mempersilakan jamaah yang tidak mendapat kesempatan melaksanakan ibadah Jum'at untuk mengerjakan shalat Zuhur di rumah masing-masing. ${ }^{32}$

\section{Menyoal Pembebasan Napi karena Covid-19}

Sudah 35 ribu lebih narapidana yang dibebaskan demi mencegah penyebaran virus Corona. Namun pembebasan tersebut justru menimbulkan masalah baru. Beberapa nabi yang dibebaskan kembali berulah hingga akhirnya dibui lagi. Perbuatan napi yang kembali berulah tersebut menambah keresahan masyarakat. Kondisi keamanan di masyarakat semakin terancam dengan para napi yang kembali berulah dan mengulangi tindak kejahatannya.

Dasar pertimbangan bahwa: (a) kondisi darurat (Covid-19) tidak boleh dihilangkan dengan mendatangkan dampak negative yang lain (al-dharar la yuzalu bi al-dharar), (b) lapas dan rutan lebih aman daripada napi dibebaskan, jika alasan pembebasan untuk menghindari virus Corona. Karena lapas dan rutan sangat tertutup dan orang ang keluarmasuk sangat dibatasi, dan (c) kasus criminal semakin tinggi paska pembebasan napi. Rekomndasi kebijakan, seharusnya Kemenkumham melakukan rapid test terlebih dahulu di lapas ataupun di rutan, sebelum menerbitkan kebijakan pembebasan narapidana yang sudah menjalani $2 / 3$ masa tahanan dan berkelakuan baik.

Maka pertanyaan yang muncul adalah tentang sikap fiqih menyikapi kebijakan Kemenkumham mengenai pembebasan narapidana dengan dalih mencegah penebaran virus Corona. Jawabannya adalah menimbang dalam hal ini Kemenkumham adalah sebagai ulil amri yang seharusnya setiap kebijakan yang dibuat mengacu pada kemaslahatan, dan semestinya sudah melalui proses pengkajian mendalam dengan melakukan musyawarah bersama pihak-pihak yang berkompeten di bidangnya, maka musyawirin menyatakan bahwa pemberlakuan asimilasi napi oleh Kemenkumham demi menghindari penyebaran Covid-19 yang berdampak pada anggaran pembiayaan Negara, hukumnya adalah boleh. Namun sebagai catatan, napi yang mendapatkan keringanan adalah meeka yang betul-betul berkelakuan baik selama di penjara, dan membuat perjanjian untuk tidak membuat keonaran di masyarakat. ${ }^{33}$

5. Akad Nikah Via Online masa-normal-baru.

32 https://www.nu.or.id/post/read/120567/lbm-pbnu-merilis-tata-cara-pelaksanaan-ibadah-jumat-pada-

${ }^{33}$ Al-Suyuthi, al-Asybah wa al-Nazhair, vol. 1, (Semarang: Toha Putra, t.th.), h. 87 dan 121, Wahbah alZuhaili, al-Fiqh al-Islami wa Adillatuhu, vol. 8, (Beirut: Dar al-Fikr, 1989.), h. 6188 dan 6202, Abu Muhammad Badruddin al-'Aini, Umdah al-Qari Syarh Shahih al-Bukhari, vol. 18, (Beirut: Dar al-Fikr, 2011), h. 176, Izzuddin bin Abdissalam, Qawaid al-Ahkam fi Mashalih al-Anam, vol. 1, (Beirut: Dar al-Kutub al-Ilmiyyah, t.th.), h. 15 dan 27, alAdab al-Nabawi, h. 89, Wazarah al-Auqaf wa al-Syu'un al-Islamiyyah, al-Mausu'ah al-Fiqhiyyah al-Kuwaitiyah, vol. 28, h. 181 . 
Organisasi Kesehatan Dunia (WHO) telah menetapkan Covid-19 sebagai pandemi global. Pemerintahan beberapa negara, termasuk Indonesia, telah menetapkan protokol kesehatan dalam upaya pencegahan penyebaran Covid-19. Salah satu cara yang dinilai paling efektif adalah physical distancing (jaga jarak kontak fisik). Meski kebijakan physical distancing diterapkan, layanan publik terkait hajat masyarakat tetap diberikan pemerintah. Salah satunya pelayanan pencatatan nikah oleh KUA. Tentu dengan memperhatikan protokol kesehatan. Biasanya dihadiri, paling tidak, oleh kedua mempelai, dua orang saksi dan wali, serta kerabat keluarga. Dengan demikian, petugas pencatat rentan tertular wabah Covid-19, sebab bersinggungan langsung dengan warga masyarakat. Di situ ada kerumunan masa, meski terbatas. Bahkan, jabat tangan dalam prosesi ijab kabul antara mempelai laki-laki dengan wali juga berpotensi menjadi media penyebaran virus. Penyebaran wabah Covid-19 dan kebijakan physical distancing dalam pencegahan bisa dipertimbangkan menjadi alasan untuk tidak melakukan akad nikah dalam satu majelis secara fisik. Bisa digantikan secara digital atau elektronik, sehingga bisa disebut e-nikah. Pencatat nikah berada di kantor, calon suami, wali dan para saksi berada di rumah masingmasing.

Pertanyaannya yang muncul adalah tentang hukum pernikahan (ijab-qabul) secara online dalam kondisi saat ini sesuai deskripsi diatas. Maka jawabannya adalah hukum nikah online sebagaimana deskripsi di atas adalah tidak sah, karena tidak memenuhi syarat-syarat nikah diantaranya hadirnya muta'qidain (wali dan calon mempelai pria) dan saksi dalam satu majlis. Namun ada pendapat lemah yang mengesahkan dengan syarat adanya saksi dari masing-masing pihak. Solusi yang ditawarkan adalah mengantisipasi dari khilafiyah ulama, maka hukum yang ditawarkan adalah pihak mempelai suami-istri melakukan taukil akad (mewakilkan) pada orang lain untuk melangsungkan akad pernikahan, dengan catatan kalau memang memungkinkan bagi pihak wakil kedua belah pihak bisa bertemu dan bertatap muka dalam satu majelis. Namun jika dipandang tidak memungkinkan bisa bertemu dan bertatap muka dalam satu mejelis ketika terjadinya akad nikah, maka boleh mengikuti pendapat yang menghukum sah akad nikah via video call dengan ketentuan sebagai berikut: (a) diyakini tidak ada peluang terjadinya penipuan komunikasi jarak jauh, dan (b) saksi dengan nyata menyaksikan dan melihat dengan jelas terjadinya ijab dan qabul bagi kedua belah pihak (suami-istri). ${ }^{34}$

\section{Mempercepat Pembayaran Zakat Fitrah}

${ }^{34}$ Abu Bakar bin Muhammad al-Hishni al-Dimasyqi, Kifayah al-Akhyar, vol. 2, (Surabaya: Maktabah Ahmad Nabhan, t.th.), h. 5, Sulaiman al-Bujairimi, Tuhfah al-Habib ala Syarh al-Khatib, vol. 3, (Mesir: al-Taqaddum alIlmiyah, t.th.), h. 335, Zainuddin al-Malibari, Fath al-Mu'in, I'anah al-Thalibin, vol. 3, (Beirut: Dar al-Fikr, 2002), h. 321, Sulaiman al-Bujairimi, Hasyiyah al-Bujairimi ala al-Khatib (Tuhfah al-Habib ala Syarh al-Khatib),vol. 3, h. 387, Hajar al-Haitami, al-Syarwani dan al-Ubbadi, Tuhfah al-Muhtaj fi Syarh al-Minhaj wa Hawasyi al-Syarwani wa al-Ubbadi, vol. 7, h. 223, al-Nawawi, al-Majmu' Syarh al-Muhaddzab, vol. 9, h. 168, Wahbah al-Zuhaili, Mausu'ah al-Fiqh alIslami al-Mu'ashir, vol. 3, h. 223-247, dan al-Fatawa al-Ashriyah. 
Sebagaimana dilansir dalam media Tempo (01/04/2020) bahwa KH. Ma'ruf Amin pada saat Konferensi Pers Virtual di Jakarta, Selasa, 31 Maret 2020 menyatakan bahwa, dalam kondisi pandemi Covid 19 seperti sekarang ini, zakat yang biasanya dibayarkan saat Ramadhan berupa zakat fitrah dapat dimajukan waktunya, dengan pertimbangan bahwa dalam kondisi seperti ini masyarakat sangat membutuhkan. Maka muncul pertanyaan tentang hukum memajukan pembayaran zakat fitrah sebelum waktunya dalam kondisi pandemi seperti saat ini. Jawaban forum DFK adalah, bahwa ulama berbeda pendapat. Menurut mayoritas (jumhur al-ulama), tidak boleh memajukan pembayaran zakat sebelum bulan Ramadhan. Namun menurut Hanafiyyah, boleh memajukan pembayaran zakat sebelum bulan Ramadhan.

Secara terperinci, ada tiga pendapat tentang hukum memajukan pembayaran zakat. Pertama, menurut mayoritas ulama, boleh mempercepat pembayaran zakat selama masih dalam bulan Ramadhan, dan tidak boleh dimajukan sebelum Ramadhan. Kedua, boleh membayar setelah terbitnya fajar pada hari pertama di bulan Ramadhan hingga akhir bulan, dan tidak boleh dibayar pada malam pertama bulan Ramadhan, karena puasanya belum dimulai. Pendapat ini diceritakan oleh al-Mutawali dan yang lainnya. Ketiga, boleh dibayarkan kapan saja selama dalam satu tahun. Pendapat ini diceritakan oleh al-Baghawi dan lainnya. ${ }^{35}$

\section{KESIMPULAN}

Salah satu usaha didalam merespon persoalan hukum, terutama seputar Covid-19 adalah dengan cara kontekstualisasi fiqih, sehingga fiqih warisan ulama masa lalu mampu berdialog dengan kondisi hari ini. Kasus-kasus di musim pandemi, sejauh ini masih bisa direspon dengan baik melalui saluran kitab-kitab otoritatif (al-kutub al-mu'tabarah) di dalam empat mazhab (Hanafi, Maliki, Syafii, dan Hanbali). Kepiawaian para ulama Indonesia, terutama peserta bahtsul masail yang tergabung dalam sebuah group WA "Diskusi Fiqih Kontemporer (DFK)" menggambarkan bagaimana teks kitab-kitab tersebut mampu merespon berbagai persoalan hukum seputar Covid-19, baik dalam hal ubudiyah, mu'amalah, munakahah, dan berbagai hukum lainnya. Memang perlu disadari, bahwa para kyai belum berani menyelesaikan hukum melalui saluran manhaji (metodologis), sehingga beberapa persoalan menjadi mauquf ketika dihadapkan pada persoalan hukum yang betulbetul baru dan tidak ada padanannya dalam kitab-kitab fiqih, baik secara langsung maupun secara tidak langsung dengan melalui analogi (ilhaq).

\footnotetext{
${ }^{35}$ Al-Nawawi, al-Majmu' Syarh al-Muhaddzab, vol. 6, h. 127-128, Wazarah al-Auqaf wa al-Syu'un alIslamiyyah, al-Mausu'ah al-Fiqhiyah al-Kuwaitiyah, vol. 23, h. 342, dan Durar al-Hukkam Syarh Gharar al-Ahkam..., vol. 1, h. 95.
} 
Terlepas dari kelemahan para ulama Indonesia, khususnya yang tergabung dalam Group WA DFK, ada secercah harapan bahwa ijtihad virtual bisa sangat efektif untuk menghadirkan para ulama yang berkompeten untuk duduk bersama menyelesaikan persoalan yang dihadapi umat, bahkan kedepan boleh jadi ijtihad virtual tidak hanya bersifat lokal (dalam negeri), melainkan juga bisa dilakukan secara lintas territorial/Negara (internasional), dan yang dibahas tidak hanya menyangkut persoalan hukum, melainkan juga menyangkut persoalan umat Islam secara global. Oleh karena itu, Kerja ijtihad harus senantiasa dilakukan agar umat mendapatkan kepastian hukum, dan ijtihad kolektif (jama'i) sangat memungkinkan dilakukan pada musim pandemi Covid-19 secara virtual, sehingga kesepakatan bersama (ijma') dapat dicapai oleh seluruh mujtahid pada era ini.

\section{DAFTAR PUSTAKA}

Abdissalam, Izzuddin bin, Qawaid al-Ahkam fi Mashalih al-Anam, vol. 1, (Beirut: Dar alKutub al-Ilmiyyah, t.th.).

'Aini, Abu Muhammad Badruddin al-, Umdah al-Qari Syarh Shahih al-Bukhari, vol. 18, (Beirut: Dar al-Fikr, 2011).

Anshari, Zakaria al-, Asna al-Mathalib fi Syarh Raudh al-Thalib, vo. 1, (Beirut: Dar alKutub al-Ilmiyyah, 2001).

Bujairimi, Sulaiman bin Muhammad al-, Hasyiyah al-Bujairimi 'ala al-Khatib, vol. 1, (Beirut: Dar al-Fikr, t.th.), h. 296.

Bujairimi, Sulaiman al-, Tuhfah al-Habib ala Syarh al-Khatib, vol. 3, (Mesir: al-Taqaddum al-Ilmiyah, t.th.).

Dimasyqi, Abu Bakar bin Muhammad al-Hishni al-, Kifayah al-Akhyar, vol. 2, (Surabaya: Maktabah Ahmad Nabhan, t.th.).

Effendi, Satria, Ushul Fiqh, 4th ed., (Jakarta: Kencana Prenada Media Group, 2012).

Fatwa MUI Nomor 31 Tahun 2020 tentang penyelenggaraan shalat jum'at dan jamaah untuk mencegah penularan wabah covid-19.

Fatwa MUI nomor 14 Tahun 2020, Buku Fiqih Pemulasaran Jenazah Pasien Covid-19 yang dikeluarkan oleh LBM-PBNU, dan Maklumat Pimpinan Pusat Muhammadiyah nomor 02/MLM/I.0/B/2020.

Haitami, Ibn Hajar al-, al-Fatawa al-Fiqhiyah al-Kubra, Vol. 1, (Mesir: al-Maktabah alIslamiyah, t.th.).

Haitami, Ibn Hajar al-, al-Syarwani dan al-Ubbadi, Tuhfah al-Muhtaj fi Syarh al-Minhaj wa Hawasyi al-Syarwani wa al-Ubbadi, vol. 1, (Beirut: Dar al-Fikr, 1997).

Haitami, Ibn Hajar al-, al-Syarwani dan al-Ubbadi, Tuhfah al-Muhtaj fi Syarh al-Minhaj wa Hawasyi al-Syarwani wa al-Ubbadi, (t.tp.: Dar Ihya' al-Turats al-Arabi, t.th). 
Iqbal, Muhammad, The Reconstruction of Religious, Thought in Islam, (New Delhi: Ktab Bavan, 1981).

Isma'il, Sya'ban, al-Ijtihad al-Jama'i wa Daur al-Majami' al-Fiqhiyyah fi Tathbiqihi, (Beirut: Dar al-Basyair, 1998).

Jamal, Sualaiman bin Umar al-, Hasyiyah al-Jamal/Futuhat al-Wahhab, vol. 1, (Beirut: Dar al-Fikr, t.th.).

Jawziyyah, Ibn al-Qayyim al-, I'lÉm al-Muwaqqi'Ên 'an Rabb al-'ÓlamÊn, vol. 1, (alRiyÉİ: DÉr Ibn al-JawzÊE, 1423 H.).

Jauziyah, Ibn Qayyim al-, I'lam al-Muwaqi'in 'an Rabb al-'Alamin, Vol. 3, (Beirut: Dar Jail, T.th.), h. 14.

Khaeruman, Badri, Hukum Islam Dalam Perubahan Sosial, (Bandung: Pustaka Setia, 2010).

Khallaf, 'Abdul Wahhab, Ilm Ushul al-Fiqh, 12th eds, (DÉr al-Qalam, 1978).

Khulashah Tarikh al-Tasyri' al-Islami, (Kuwait: Dar al-Qalam, t.th.).

Madjid, Nurcholish, Taklid dan Ijtihad: Masalah Kontinuitas dan Kreativitas dalam Memahami Pesan Agama, norcholishmadjid.org/arsip-karya/read/7-1994-taklid-danijtihad.

Mahfudh, Sahal, Nuansa Fiqh Sosial, 7th ed., (Yogyakarta: LKiS, 2011), h. xxxix-xI.

Malibari, Zainuddin al-, Fath al-Mu'in, I'anah al-Thalibin, vol. 3, (Beirut: Dar al-Fikr, 2002).

Maliki, Abu al-Qasim Ibn al-Syath al-, Idrar al-Syuruq 'ala Anwa' al-Furuq, Vol. 4, (Beirut: Dar al-Kutub al-'Ilmiyyah, t.th).

Nawawi, Muhyiddin al-, al-Majmu’ Syarh al-Muhadzab, Vol. 5, (Beirut: Dar al-Kotob alIlmiyyah, 2011).

Nawawi, Muhammad bin Umar, Nihayah al-Zain Syarh Qurrah al-'Ain, (Beirut: Dar alFikr, 1995).

QarÉf̂̂, AÍmad bin IdrÊs al-, al-FurËq, vol. 1, (BeirËt: DÉr al-Kutub al-'Ilmiyyah, 1998).

Qulyubi, al- dan 'Umairah, HÉsyiyata Qulyubi wa 'Umairah, Vol. 11, (al-Qahirah: Dar alTaufiqiyah li al-Turats, 2010).

Sanu, Quthb, al-Ijtihad al-Jama’i al-Mansyud, (Dar al-Nafais, 2006).

Syarafi, Abdul Majid al-Susuh al-, al-Ijtihad al-Jama’i fi al-Tasyri' al-Islami, (Wizarah alAuqaf wa al-Syu'un al-Islamiyah: Silsislah Kitab al-Ummah, 1418 H.).

Syarbini, Muhammad bin Ahmad al-, Mughni al-Muhtaj ila Ma'rifah Alfazh al-Minhaj, vol. 1, (Mesir: al-Tijariyah al-Kubra, t.th.).

Suyuthi, Abdurrahman bin Abi Bakr al-, al-Asybah wa al-Nazhair, vol. 1, (Semarang: Toha Putra, t.th.). 
Wazarah al-Auqaf wa al-Syu'un al-Islamiyyah, al-Mausu'ah al-Fiqhiyah al-Kuwaitiyah, (Kuwait: Dzat as-Salasil, 1983).

Zahro, Ahmad, "Desakralisasi Kitab Fiqih Sebagai Upaya Reformasi Pemahaman Hukum Islam." yang disampaikan dalam pengukuhan guru besar ilmu fikih (hukum Islam) Fakultas Tarbiyah IAIN Sunan Ampel (sekarang UINSA), 30 Juli 2005.

Zarqa, Muhammad al-, Syarh al-Qawaid al-Fiqhiyyat, (Damaskus: Darul Qalam, 1989).

Zuhaili, Wahbah al-, al-Fiqh al-Islami wa Adillatuhu, vol. 8, (Beirut: Dar al-Fikr, 1989).

Zuhaili, Wahbah al-, Mausu'ah al-Fiqh al-Islami al-Mu'ashir, vol. 3, (Beirut: Dar al-Fikr, 2017).

https://Id.m.wiktionary.org/wiki/virtual

https://chat.whatsapp.com/EBExnbQIPy QEnysKazvqZI

www.pakarfiqih.blogspot.com.

https://www.nu.or.id/post/read/120567/lbm-pbnu-merilis-tata-cara-pelaksanaan-ibadahjumat-pada-masa-normal-baru. 